University of Nebraska - Lincoln

DigitalCommons@University of Nebraska - Lincoln

\title{
Chronology of sediment deposition in Upper Klamath Lake, Oregon
}

Steven M. Colman

US Geological Survey, 384 Woods Hole Rd., Woods Hole, MA 02543, USA

J. Platt Bradbury

5784 Horseradish Gulch, Golden, C0 80403, USA

John P. McGeehin

US Geological Survey, National Center MS 955, Reston, VA 20192, USA

Charles W. Holmes

US Geological Survey, 600 4th Street South, St. Petersburg, FL 33701, USA

David Edginton

Center for Great Lakes Studies, University of Wisconsin, Milwaukee, WI 53204, USA

See next page for additional authors

Follow this and additional works at: https://digitalcommons.unl.edu/usgsstaffpub

Part of the Earth Sciences Commons

Colman, Steven M.; Bradbury, J. Platt; McGeehin, John P.; Holmes, Charles W.; Edginton, David; and SarnaWojcicki, Andrei M., "Chronology of sediment deposition in Upper Klamath Lake, Oregon" (2004). USGS

Staff -- Published Research. 282.

https://digitalcommons.unl.edu/usgsstaffpub/282

This Article is brought to you for free and open access by the US Geological Survey at DigitalCommons@University of Nebraska - Lincoln. It has been accepted for inclusion in USGS Staff -- Published Research by an authorized administrator of DigitalCommons@University of Nebraska - Lincoln. 


\section{Authors}

Steven M. Colman, J. Platt Bradbury, John P. McGeehin, Charles W. Holmes, David Edginton, and Andrei M. Sarna-Wojcicki 
This article is a U.S. government work, and is not subject to copyright in the United States.

\title{
Chronology of sediment deposition in Upper Klamath Lake, Oregon ${ }^{\star}$
}

\author{
Steven M. Colman ${ }^{1, *}$, J. Platt Bradbury ${ }^{2}$, John P. McGeehin ${ }^{3}$, Charles W. Holmes ${ }^{4}$, \\ David Edginton ${ }^{5}$ and Andrei M. Sarna-Wojcicki ${ }^{6}$ \\ ${ }^{1}$ US Geological Survey, 384 Woods Hole Rd., Woods Hole, MA 02543, USA; ${ }^{2} 5784$ Horseradish Gulch, \\ Golden, CO 80403, USA; ${ }^{3}$ US Geological Survey, National Center MS 955, Reston, VA 20192, USA; \\ ${ }^{4}$ US Geological Survey, 600 4th Street South, St. Petersburg, FL 33701, USA; ${ }^{5}$ Center for Great \\ Lakes Studies, University of Wisconsin, Milwaukee, WI 53204, USA; ${ }^{6}$ US Geological Survey, \\ 345 Middlefield Rd. MS 975, Menlo Park, CA 94025, USA; *Author for correspondence \\ (e-mail:scolman@usgs.gov)
}

Received 1 May 2002; accepted in revised form 2 July 2003

Key words: ${ }^{137} \mathrm{Cs},{ }^{210} \mathrm{~Pb}$, Radiocarbon, Paleoclimate, Paleolimnology, Tephrochronology, Upper Klamath Lake

\begin{abstract}
A combination of tephrochronology and ${ }^{14} \mathrm{C},{ }^{210} \mathrm{~Pb}$, and ${ }^{137} \mathrm{Cs}$ measurements provides a robust chronology for sedimentation in Upper Klamath Lake during the last 45000 years. Mixing of surficial sediments and possible mobility of the radio-isotopes limit the usefulness of the ${ }^{137} \mathrm{Cs}$ and ${ }^{210} \mathrm{~Pb}$ data, but ${ }^{210} \mathrm{~Pb}$ profiles provide reasonable average sediment accumulation rates for the last 100-150 years. Radiocarbon ages near the top of the core are somewhat erratic and are too old, probably as a result of detrital organic carbon, which may have become a more common component in recent times as surrounding marshes were drained. Below the tops of the cores, radiocarbon ages in the center of the basin appear to be about 400 years too old, while those on the margin appear to be accurate, based on comparisons with tephra layers of known age.

Taken together, the data can be combined into reasonable age models for each site. Sediments have accumulated at site K1, near the center of the basin, about 2 times faster than at site CM2, on the margin of the lake. The rates are about 0.10 and $0.05 \mathrm{~cm} / \mathrm{yr}$, respectively. The chronological data also indicate that accumulation rates were slower during the early to middle Holocene than during the late Holocene, consistent with increasing wetness in the late Holocene.
\end{abstract}

\section{Introduction}

The setting of Upper Klamath lake is described in some detail in the introduction to this issue (Colman et al. 2004 - this issue). The most impor-

\footnotetext{
$\star^{\star}$ This is the second in a series of eight papers published in this special issue, resulting from paleoenvironmental studies in the Upper Klamath Lake Basin. These studies were conducted by the US Geological Survey and its collaborators as part of a paleoclimate research effort called the Correlation of Marine and Terrestrial Records Project. Steven M. Colman served as a guest editor of this special issue.
}

tant background information for this paper is that Upper Klamath Lake is large, shallow, and through-flowing, so that its water is fresh and has a short residence time. Bottom sediments in the lake are commonly resuspended by wind-generated currents (Laenen and LeTourneau 1996).

In this paper, we develop chronological models for the deposition of sediments recovered in cores collected in Upper Klamath Lake and from its margins. We focus on two sites (Colman et al. 2004 - this issue, their Figure 2): (1) the edge of Caledonia Marsh, the location of a $12.9-\mathrm{m}$ 
Livingstone core (CM2), and (2) the north-central part of the lake, the site of a 9.1-m Livingstone core (K1). Additional data come from several secondary sites. Age information for the sediments was derived from ${ }^{210} \mathrm{~Pb}$ and ${ }^{137} \mathrm{Cs}$ analyses, radiocarbon ages, and the presence of tephra units of known age. We discuss each of these methods and the resulting age information before developing age models for individual core sites.

\section{Methods and results}

\section{Cores and sediments}

In addition to the two main cores (CM2 and K1), additional secondary cores were collected. These include a 1.6-m Livingstone core (HB) take about $400 \mathrm{~m}$ offshore of CM2 in Howard Bay, short gravity cores $(\mathrm{C} 7)$ that were collected at the site of core $\mathrm{K} 1$, and additional short gravity cores collected for ${ }^{210} \mathrm{~Pb}$ and ${ }^{137} \mathrm{Cs}$ analyses at two other sites (C6 and C8). Details for these cores are given in Colman et al. (2004 - this issue).

The gravity cores were collected using a smalldiameter gravity corer with a messenger-triggered seal. This corer appeared to recover a complete and undisturbed sample of the sediments, commonly including an algal mat at the sediment surface. The Livingstone (Wright 1967) cores at sites CM2 and $\mathrm{HB}$ also appear to be undisturbed. However, comparisons between diatom stratigraphic markers in cores $\mathrm{K} 1$ and $\mathrm{C} 7 \mathrm{~A}$, collected at the same site, suggests that about $8 \mathrm{~cm}$ of sediment were missing from the top of core K1. Depths in core $\mathrm{K} 1$ were corrected by this amount, as well as for compaction during extrusion.

Core CM2 contains mostly diatomaceous muds deposited in open lake environments, but its upper part grades into marsh deposits similar to those forming at the site today. Core $\mathrm{HB}$ was collected near CM2, from shallow water in Howard Bay. Core $\mathrm{K} 1$ and the gravity cores were collected in sites in the open part of the present lake, in part to provide a continuous open-lake record when combined with the longer CM2 record. Cores HB, $\mathrm{K} 1$, and the gravity cores contain only diatomaceous muds. The lithology of these cores is discussed in more detail in (Bradbury et al. 2004a - this issue).

$$
{ }^{210} \mathrm{~Pb} \text { and }{ }^{137} \mathrm{Cs}
$$

${ }^{210} \mathrm{~Pb}$ was measured by standard alpha-counting methods on samples from three short gravity cores in Upper Klamath Lake. Supported ${ }^{210} \mathrm{~Pb}$ (i.e., that in equilibrium with uranium-series elements in the sediments) was estimated from the values at depth in the core, and excess ${ }^{210} \mathrm{~Pb}$ was calculated by difference from the total. The resulting profiles of excess ${ }^{210} \mathrm{~Pb}$ with depth (Figure 1) are similar to those obtained by Martin and Rice (1981) and Eilers et al. (in press) for the lake. In particular, many of the profiles both here and in the other cited studies have relatively constant values of excess ${ }^{210} \mathrm{~Pb}$ in their upper few $\mathrm{cm}$. This zone of nearly constant concentration is commonly attributed to surface mixing processes, although it can also be due, at least in part, to an acceleration of sediment accumulation in recent times. Because of the demonstrated prevalence of wind-driven resuspension of the diatomaceous sediments in Upper Klamath Lake (Bond et al. 1968; Laenen and LeTourneau 1996), we attribute the nearsurface zone of constant ${ }^{210} \mathrm{~Pb}$ concentrations primarily to physical mixing.

The total ${ }^{210} \mathrm{~Pb}$ inventories for cores in Upper Klamath Lake are relatively low and variable, 2-10 $\mathrm{dpm} / \mathrm{g}$ per $\mathrm{cm}^{2}$ in this study. Other studies (Martin and Rice 1981; Eilers et al. in press) also have obtained low and variable inventories (3-30 dpm/ $\mathrm{g}$ per $\mathrm{cm}^{2}$ ), although with more sampling sites, Martin and Rice (1981) obtained some relatively high values. These values compare to $35 \mathrm{dpm} / \mathrm{g}$ per $\mathrm{cm}^{2}$ for a core in nearby Lake of the Woods (C.W. Holmes and S.M. Colman, unpublished data). The reason for the low total ${ }^{210} \mathrm{~Pb}$ inventories is not known, but the low mineral content of the sediments and the short residence time of water (and suspended sediment) in the lake may be involved.

Analyses of the ${ }^{210} \mathrm{~Pb}$ profiles at our three core sites (Figure 1) yields age information for the last $100-150$ years. Estimating ages from ${ }^{210} \mathrm{~Pb}$ profiles is complex and involves many assumptions and approximations, which are reviewed by Robbins (1978) and Oldfield et al. (1984), for example. Methods for estimating ages use one of two major assumptions: (1) that the concentration of unsupported ${ }^{210} \mathrm{~Pb}$ at the time of deposition is constant (Robbins and Edgington 1975), or (2) that the 

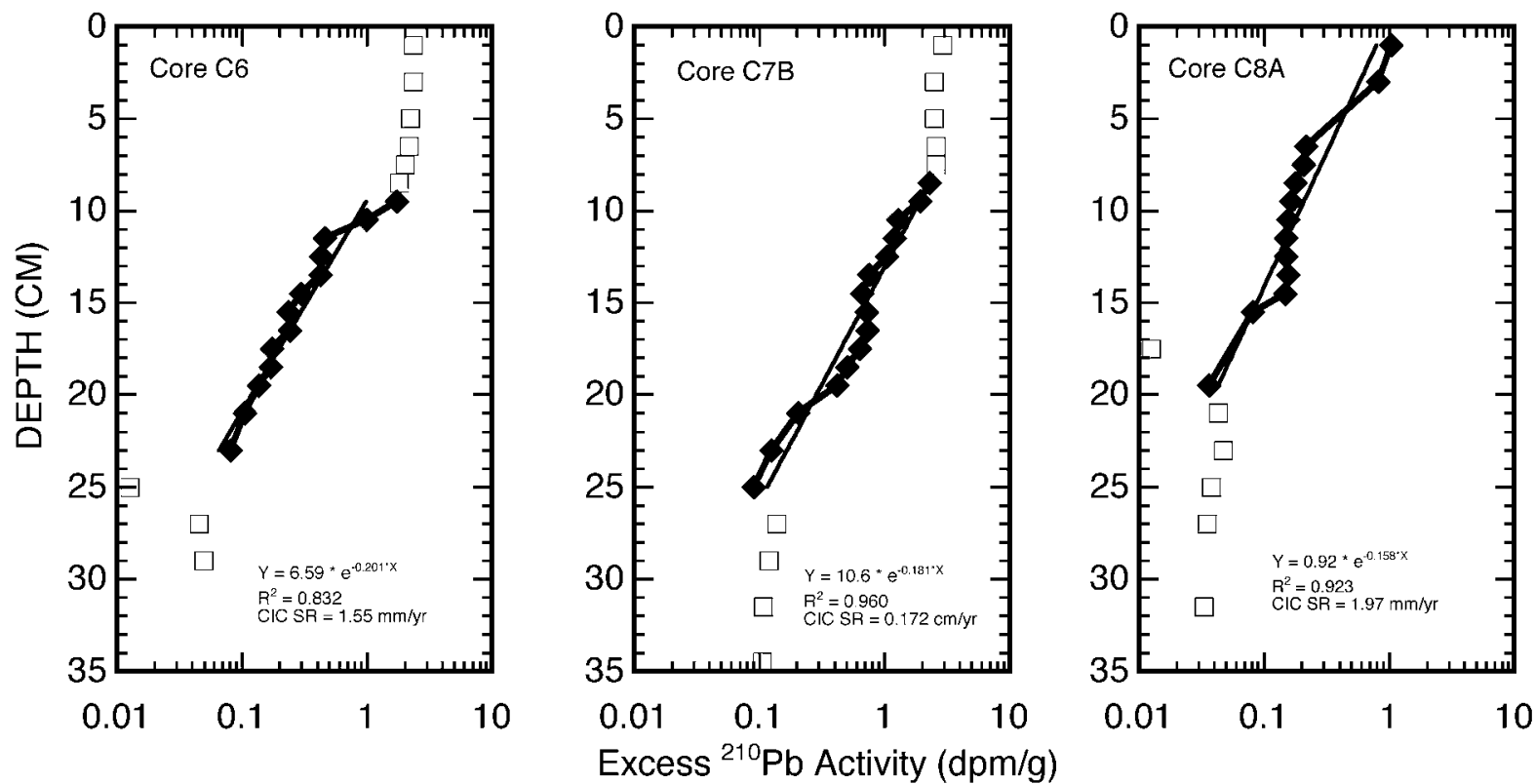

Figure 1. ${ }^{210} \mathrm{~Pb}$ data plotted against depth for three gravity cores in Upper Klamath Lake. Core locations shown in Figure 2 of Colman et al. (2004 - this issue).

supply of ${ }^{210} \mathrm{~Pb}$ is constant despite changes in mass accumulation rates and (or) initial ${ }^{210} \mathrm{~Pb}$ concentration (Appleby and Oldfield 1978; Oldfield et al. 1984). Some calculation methods using the first assumption are called the constant initial concentration (CIC) method; techniques using the second assumption are called the constant rate of supply (CRS) method. Both methods can be modified to account for sediment mixing.

Uncertainties about the local rate of supply of ${ }^{210} \mathrm{~Pb}$ at Upper Klamath Lake and complexities in historic depositional processes make precise age estimates based on ${ }^{210} \mathrm{~Pb}$ difficult. In particular, because of its shallow depth, wind conditions that generate bottom shear stresses sufficient to resuspend the bottom are relatively common in Upper Klamath Lake (Bond et al. 1968; Laenen and LeTourneau 1996). Surface mixing and (or) episodic deposition is suggested by nearly constant values of ${ }^{210} \mathrm{~Pb}$ in the upper part of many profiles and by small scale steps in the profiles with depth (Figure 1, Martin and Rice 1981; Eilers et al. in press). Because of these complexities, we only attempted to calculate average sedimentation rates for the historic period (Table 1), rather than exact ages of specific horizons, from the ${ }^{210} \mathrm{~Pb}$ data. Consequently, ages estimated from these average
Table 1. Summary of values derived from ${ }^{210} \mathrm{~Pb}$ data.

\begin{tabular}{lcll}
\hline & & \multicolumn{2}{l}{$\begin{array}{l}\text { Average sedimentation } \\
\operatorname{rate}^{\mathrm{b}}(\mathrm{cm} / \mathrm{yr})\end{array}$} \\
\cline { 3 - 4 } Core & $\begin{array}{l}{ }^{210} \mathrm{~Pb} \text { Inventory } \\
\left(\mathrm{dpm} / \mathrm{g} \text { per } \mathrm{cm}^{2}\right)\end{array}$ & $\mathrm{CIC}^{\mathrm{c}}$ & $\mathrm{CRS}^{\mathrm{c}}$ \\
\hline $\mathrm{C} 6$ & 7.8 & 0.155 & 0.181 \\
$\mathrm{C} 7 \mathrm{~B}$ & 9.5 & 0.172 & 0.157 \\
$\mathrm{C} 8 \mathrm{~A}$ & 1.8 & 0.197 & 0.276 \\
$\mathrm{C}^{\mathrm{a}}$ & 35.4 & 0.102 & 0.105 \\
\hline
\end{tabular}

${ }^{\mathrm{a}}$ From Lake of the Woods.

${ }^{\mathrm{b}}$ Rates calculated for intervals below the near-surface zone of nearly constant ${ }^{210} \mathrm{~Pb}$ values.

${ }^{\mathrm{c}} \mathrm{See}$ text for discussion of these methods.

sediment accumulation rates carry uncertainties of perhaps $\pm 10-20$ years.

We calculated average sediment-accumulation rates $\left(\mathrm{g} / \mathrm{cm}^{2}\right.$ per year) using both the CIC method and the CRS method, along with density measurements. In addition to other uncertainties, the CRS method is sensitive to our assumption that ${ }^{210} \mathrm{~Pb}$ values at depth in the cores represent the supported ${ }^{210} \mathrm{~Pb}$ value in the core. Because of these uncertainties, in using the CRS method, we used only the mean of incremental sediment accumulation rates calculated between individual horizons (excluding the intervals of constant ${ }^{210} \mathrm{~Pb}$ values at the top of 
the cores), rather than calculating specific ages for individual horizons. The sediment accumulation rates $\left(\mathrm{g} / \mathrm{cm}^{2}\right.$ per year) calculated by both methods were then converted to average sedimentation rates ( $\mathrm{cm} / \mathrm{yr}$ ), so that they could be compared with radiocarbon-derived sedimentation rates.

Below the constant ${ }^{210} \mathrm{~Pb}$ values near the tops of the cores, segments of ${ }^{210} \mathrm{~Pb}$ profiles that form exponential (i.e., decay) curves with depth suggest intervals with relatively constant sediment accumulation rates, which can be calculated directly from the plots of excess ${ }^{210} \mathrm{~Pb}$ with depth. This method, along with the CIC and CRS methods, all yield comparable average sedimentation rates for our cores (Table 1).

The consistency of these results, $0.15-0.20 \mathrm{~cm} / \mathrm{yr}$ for the three Upper Klamath Lake cores (Table 1), suggests that they are reasonable average sedimentation rates for the past century or so. The rate for C7, also the location of long core $\mathrm{K} 1$, is $0.172 \mathrm{~cm} / \mathrm{yr}$, which will be used in the development of a longer term age model based on radiocarbon analyses in a later section.

${ }^{137} \mathrm{Cs}$ occurs in core C8A at depths that appear to be anomalously great (Figure 2). With no mixing and a sedimentation rate of $0.197 \mathrm{~cm} / \mathrm{yr}$ from the ${ }^{210} \mathrm{~Pb}$ data for that site (Figure 1), the 1963 peak in ${ }^{137} \mathrm{Cs}$ should be at a depth of $6.5 \mathrm{~cm}$. Instead, the distribution is in the form of a broad peak centered at $19 \mathrm{~cm}$. Core $\mathrm{C} 2$ in Lake of the Woods shows a similar pattern in ${ }^{137} \mathrm{Cs}$ distribution. Downward mobility of ${ }^{137} \mathrm{Cs}$ has been shown to occur in other shallow lakes (e.g., Brenner et al. 1994; Schelske et al. 1994), although neither continuous mixing nor downward mobility can entirely explain the observed distribution. One possible explanation is a single large mixing event shortly after 1963, combined with continued smaller scale mixing and some ${ }^{137} \mathrm{Cs}$ mobility. The ${ }^{210} \mathrm{~Pb}$ data (Figure 1) would allow this scenario, but no independent evidence exists to support it.

\section{Radiocarbon}

Very few radiocarbon ages have been obtained previously for sediments of Upper Klamath Lake. Sanville et al. (1974) reported several conventional ${ }^{14} \mathrm{C}$ ages on bulk sediments at three sites. The sequences of ages with depth contained several

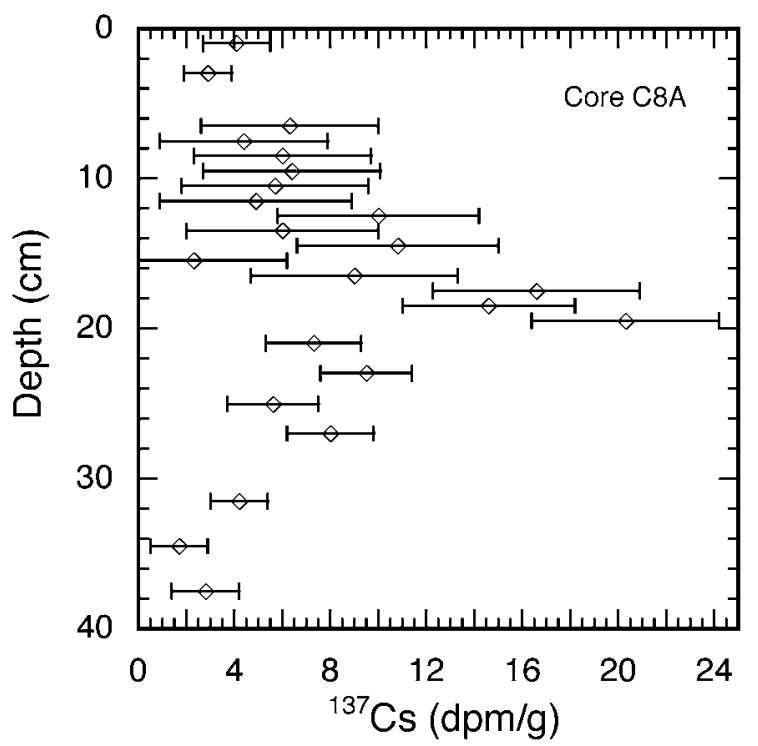

Figure 2. ${ }^{137} \mathrm{Cs}$ data plotted against depth for core C8A. Core location shown in Figure 2 of Colman et al. (2004 - this issue).

reversals and ages of more than 4000 years were obtained at depths of less than $1 \mathrm{~m}$. In contrast, Eilers et al. (in press) reported radiocarbon ages of $1420 \mathrm{yr} \mathrm{BP}$ at $65.5 \mathrm{~cm}$ at one site, and $1460 \mathrm{yr} \mathrm{BP}$ at $65 \mathrm{~cm}$ at another.

We determined radiocarbon ages for Upper Klamath Lake sediments using accelerator-mass spectrometry (AMS) methods, primarily on total organic carbon (TOC) in the samples. Macroscopic organic matter is extremely rare in the sediments we examined, and only a few pieces of wood were found and analyzed (Table 2). Most samples were diatomaceous oozes or lacustrine muds, for which most of the organic matter is assumed to be endogenic (produced in the lake). Organic carbon contents in the sediments are high in the post-glacial sediments, typically $3-8 \%$, and moderately low in the glacial sediments, typically $0.25-0.75 \%$ (W.E. Dean, written commun.). For these relatively carbon-rich, carbonate-free, fine-grained sediments that have been continuously submerged, we assumed that movement of dissolved carbon in pore water had negligible effects on radiocarbon contents.

Organic carbon samples were acidified with organic-free $\mathrm{HCl}$ and placed in reaction tubes along with $2 \mathrm{~g}$ of copper oxide and a 2-by-12-mm strip of silver foil. The tubes were evacuated, flame 
Table 2. Radiocarbon ages ${ }^{\mathrm{a}}$.

\begin{tabular}{|c|c|c|c|c|c|c|c|c|c|}
\hline \multicolumn{2}{|c|}{$\begin{array}{l}\text { Core and } \\
\text { laboratory numbers }\end{array}$} & \multirow{2}{*}{$\begin{array}{l}\text { Depth } \\
(\mathrm{cm})\end{array}$} & \multirow{2}{*}{$\begin{array}{l}\text { Corrected } \\
\text { depth } \\
(\mathrm{cm})^{\mathrm{b}}\end{array}$} & \multirow{2}{*}{$\begin{array}{l}\text { Age } \\
\left(10^{3}{ }^{14} \mathrm{C}\right. \\
\text { yr Bp) }\end{array}$} & \multirow{2}{*}{$\begin{array}{l}\text { Error } \\
\left(10^{314} \mathrm{C}\right. \\
\text { yr Bp) }\end{array}$} & \multirow{2}{*}{$\begin{array}{l}\text { Age } \\
\left(10^{3} \text { cal yr }\right)\end{array}$} & \multirow{2}{*}{$\begin{array}{l}\text { Range of } \\
\text { cal age } \\
\left(10^{3} \text { cal yr }\right)\end{array}$} & \multirow[b]{2}{*}{ Material $^{\mathrm{d}}$} & \multirow[b]{2}{*}{ Comment } \\
\hline WW & CAMS & & & & & & & & \\
\hline \multicolumn{10}{|c|}{ Core K1 } \\
\hline 1209 & 38112 & 1 & 9.2 & 0.89 & 0.04 & 0.52 & $+0.10 /-0.02$ & TOC & Not used, near surface \\
\hline 1210 & 38113 & 26 & 38.4 & 1.19 & 0.05 & 0.69 & $+0.10 /-0.03$ & TOC & Not used, near surface \\
\hline 1211 & 38114 & 54 & 71.1 & 1.46 & 0.05 & 0.96 & $+0.10 /-0.15$ & TOC & Not used, near surface \\
\hline 1212 & 38115 & 88 & 107.2 & 1.46 & 0.05 & 0.96 & $+0.10 /-0.15$ & TOC & Not used, near surface \\
\hline 1213 & 38116 & 150 & 181.3 & 2.08 & 0.05 & 1.56 & $+0.15 /-0.14$ & TOC & \\
\hline 1214 & 38117 & 200 & 234.4 & 2.52 & 0.05 & 2.12 & $+0.18 /-0.17$ & TOC & \\
\hline 1215 & 38118 & 300 & 341.8 & 3.52 & 0.05 & 3.36 & $+0.10 /-0.15$ & TOC & \\
\hline 1216 & 38119 & 500 & 555.2 & 5.17 & 0.07 & 5.53 & $+0.11 /-0.21$ & TOC & \\
\hline 1217 & 38120 & 600 & 659.2 & 6.91 & 0.05 & 7.43 & $+0.12 /-0.11$ & TOC & \\
\hline 1218 & 38121 & 641 & 700.7 & 7.26 & 0.06 & 7.68 & $+0.11 /-0.09$ & TOC & Near Mazama \\
\hline 1219 & 38122 & 647 & 706.8 & 7.31 & 0.05 & 7.71 & $+0.13 /-0.09$ & TOC & Near Mazama \\
\hline 1220 & 38123 & 650 & 709.8 & 7.30 & 0.05 & 7.69 & $+0.13 /-0.08$ & TOC & Near Mazama \\
\hline 1221 & 38124 & 653 & 712.8 & 7.33 & 0.05 & 7.75 & $+0.17 /-0.08$ & TOC & Near Mazama \\
\hline 1222 & 38125 & 750 & 810.9 & 10.32 & 0.05 & 11.26 & $+0.29 /-0.06$ & TOC & \\
\hline 1224 & 38126 & 750 & 810.9 & 11.83 & 0.06 & 13.43 & $+0.37 /-0.28$ & wood & Not used, detrital \\
\hline 1225 & 38127 & 833 & 898.0 & 12.37 & 0.05 & 13.91 & $+1.39 /-0.26$ & wood & Not used, detrital \\
\hline \multicolumn{10}{|c|}{ Core C7B } \\
\hline 1243 & 38369 & 1 & 1.0 & 0.29 & 0.05 & 0 & - & TOC & \\
\hline 1244 & 38370 & 16 & 16.0 & 0.72 & 0.05 & 0.39 & $+0.11 /-0.10$ & TOC & Not used, near surface \\
\hline 1245 & 38371 & 26 & 26.0 & 1.01 & 0.04 & 0.60 & $+0.06 /-0.06$ & TOC & Not used, near surface \\
\hline \multicolumn{10}{|c|}{ Core C8B } \\
\hline 1205 & 38108 & 1 & 1.0 & 0.53 & 0.04 & 0.14 & $+0.15 /-0.14$ & TOC & Not used, near surface \\
\hline 1206 & 38109 & 10 & 10.0 & 0.77 & 0.05 & 0.46 & $+0.05 /-0.15$ & TOC & Not used, near surface \\
\hline 1207 & 38110 & 25 & 25.0 & 0.97 & 0.05 & 0.61 & $+0.04 /-0.10$ & TOC & Not used, near surface \\
\hline 1208 & 38111 & 54 & 54.0 & 1.39 & 0.04 & 0.93 & $+0.04 /-0.14$ & TOC & Not used, near surface \\
\hline \multicolumn{10}{|c|}{ Core CM2 } \\
\hline 359 & 14791 & 50 & 50 & 2.72 & 0.06 & 2.83 & $+0.09 /-0.08$ & TOC & \\
\hline 360 & 14792 & 110 & 110 & 3.59 & 0.07 & 3.88 & $+0.18 /-0.15$ & TOC & \\
\hline 264 & 12655 & 202 & 202 & 5.44 & 0.06 & 6.22 & $+0.08 /-0.10$ & TOC & \\
\hline 265 & 12656 & 248 & 248 & 5.76 & 0.06 & 6.55 & $+0.17 /-0.14$ & TOC & \\
\hline 266 & 12657 & 300 & 300 & 6.59 & 0.07 & 7.47 & $+0.10 /-0.04$ & TOC & \\
\hline 267 & 12658 & 323 & 323 & 6.79 & 0.07 & 7.63 & $+0.05 /-0.06$ & TOC & \\
\hline 273 & 12662 & 388 & 388 & 8.68 & 0.08 & 9.59 & $+0.30 /-0.05$ & TOC & \\
\hline 361 & 14793 & 458 & 458 & 11.35 & 0.09 & 13.25 & $+0.53 /-0.21$ & TOC & \\
\hline 274 & 12663 & 468 & 468 & 12.03 & 0.11 & 14.08 & $+1.25 /-0.41$ & TOC & \\
\hline 268 & 12659 & 530 & 530 & 13.76 & 0.13 & 16.51 & $+0.49 /-0.44$ & TOC & \\
\hline 362 & 14794 & 620 & 620 & 14.61 & 0.14 & 17.49 & $+0.54 /-0.48$ & TOC & \\
\hline 269 & 12660 & 700 & 700 & 15.38 & 0.16 & 18.38 & $+0.60 /-0.53$ & TOC & \\
\hline 275 & 12664 & 805 & 805 & 18.92 & 0.24 & 22.45 & $+0.75 /-0.67$ & TOC & \\
\hline 270 & 12661 & 899 & 899 & 20.99 & 0.32 & 24.74 & - & TOC & \\
\hline 363 & 14795 & 1000 & 1000 & 28.86 & 0.87 & 33.70 & - & TOC & \\
\hline 276 & 12665 & 1075 & 1075 & 28.08 & 0.79 & 32.83 & - & TOC & \\
\hline 364 & 14796 & 1225 & 1225 & 24.22 & 0.48 & 26.46 & - & TOC & Not used, age reversal \\
\hline \multicolumn{10}{|c|}{ Core HB } \\
\hline 366 & 14797 & 19.5 & 19.5 & 1.49 & 0.07 & 1.35 & $+0.16 /-0.05$ & TOC & Not used, near surface \\
\hline 367 & 15596 & 62 & 62 & 2.22 & 0.06 & 2.20 & $+0.14 /-0.08$ & TOC & \\
\hline 368 & 15597 & 133 & 133 & 4.58 & 0.07 & 5.31 & $+0.14 /-0.26$ & TOC & \\
\hline
\end{tabular}

${ }^{\text {a}}$ All ages by accelerator-mass spectrometer methods (see text); Samples were prepared in the USGS graphite laboratory (WW numbers) and analyzed at the Lawrence Livermore AMS facility (CAMS numbers). $\delta^{13} \mathrm{C}$ values of $-25 \%$ are assumed.

${ }^{\mathrm{b}}$ Includes correction for compaction and missing top in core $\mathrm{K} 1$.

${ }^{\mathrm{c}}$ Includes correction of -400 years for samples in core K1, C7B, and C8B. Calibrated ages calculated with CALIB 4.3 (Stuiver et al. 1998). Calibrated ages for ${ }^{14} \mathrm{C}$ ages $>20265$ are based on equation in Bard et al. (1998).

${ }^{\mathrm{d}} \mathrm{TOC}$ - total organic carbon. 

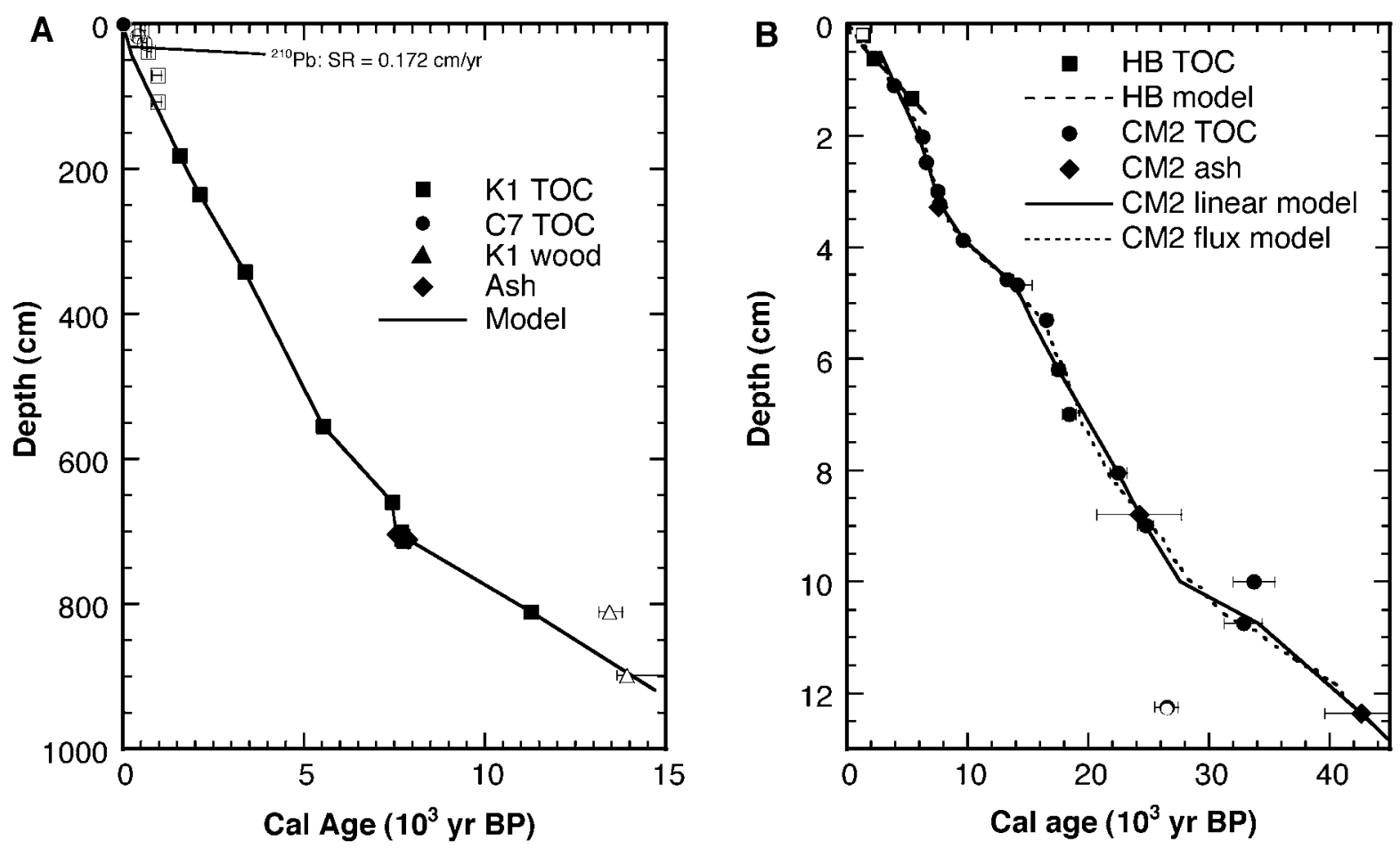

Figure 3. Age-depth models in calibrated yr BP plotted with calibrated ages of sediments samples. Open symbols indicate data not used in age model (see text). Calibrated radiocarbon ages of tephra units (Table 2) are also plotted. (A) C7A and K1; (B) CM2 and HB. Two age models are shown for CM2, one based on local linear best-fit ('linear') and the other based on sediment flux data ('flux,' Rosenbaum and Reynolds 2004 - this issue). See text for further discussion.

sealed, and then heated in a muffle furnace at $550{ }^{\circ} \mathrm{C}$ for $5 \mathrm{~h}$ to convert organic carbon to carbon dioxide. Carbon dioxide from the samples was reduced to elemental graphite over hot iron in the presence of hydrogen (Vogel et al. 1984). The graphite targets were analyzed at the Lawrence Livermore CAMS Facility. Ages were calculated using an assumed $\delta^{13} \mathrm{C}$ value of $-25 \%$, according to the methods of Stuiver and Pollach (1977). Results are reported in Table 2 and are plotted in Figure 3.

In general, the radiocarbon ages are highly coherent, showing anomalies (reversals) only for two ages in the lower part of core CM2 (Figure 3). The relatively consistent progression of ages in each core supports our assumption that much of the carbon in the lake is endogenic and was produced close to the time it was deposited with the sediments, as might be expected in a lake with high diatom and algal productivity. Two ages on detrital wood in core $\mathrm{K} 1$ were obtained, one of which is close to the age expected from the trend of the TOC ages and one that is considerably older (Figure 3A). The wood is allogenic, so the wood ages must be the same or older than the associated TOC ages.

Tephra

Tephra layers were found at several levels in cores $\mathrm{CM} 2$ and $\mathrm{K} 1$ and were identified by microprobe analysis of included volcanic glass (cf. SarnaWojcicki et al. 1991). The tephra occurrences and their ages are summarized in Table 3. These tephra horizons serve as important anchors for the chronology of the cores.

\section{Discussion and age models}

The ${ }^{210} \mathrm{~Pb}$ data suggest that sediments are accumulating in present-day Upper Klamath Lake at a rate 
Table 3. Tephra units found in cores CM2 and K1.

\begin{tabular}{lccllll}
\hline & \multicolumn{2}{c}{ Depth $(\mathrm{cm})$} & & \multicolumn{2}{c}{$\operatorname{Age}^{\mathrm{a}}\left(10^{3} \mathrm{yr}\right.$ BP $)$} \\
\cline { 2 - 3 } \cline { 5 - 6 } Tephra unit & $\mathrm{CM} 2$ & $\mathrm{~K} 1$ & & ${ }^{14} \mathrm{C}$ yr BP & cal yr BP \\
\hline Glass Mountain & 19.5 & & & ca. 1 & ca.1 \\
Mazama & 328 & 704 & & 6.73 & 7.55 \\
Tsoyowata & & 711 & & 7.015 & 7.87 \\
Trego Hot Springs & 880 & & & $17-24$ & 24.2 \\
Mount St. Helens 'C' & 1236 & & & ca. 37 & 42.6 \\
\hline
\end{tabular}

${ }^{a}$ Radiocarbon ages are from Sarna-Wojcicki et al. (1991), except for the age for the Mazama, which is from Hallet et al. (1997).

of about $0.15-0.20 \mathrm{~cm} / \mathrm{yr}$. Detailed variations in sedimentation rate are difficult to determine because of episodic physical mixing. This mixing is apparent in the ${ }^{210} \mathrm{~Pb}$ profiles themselves, and is well documented from studies of wave energy (Bond et al. 1968; Laenen and LeTourneau 1996) and nutrient cycling (Sanville et al. 1974; Kann 1997) in the lake. The ${ }^{137} \mathrm{Cs}$ data are not useful for estimating the ages of the uppermost sediments, but they demonstrate that the ${ }^{137} \mathrm{Cs}$ inventory, and presumably the sediment, probably has not been lost from the top of the sections in which they were measured.

The uncertainties in ages calculated from the ${ }^{210} \mathrm{~Pb}$-derived sediment accumulation rates are difficult to estimate. Qualitatively, any age estimated from these rates probably carries an uncertainty of 10-20 years. In core C7B, the thickness of the zone of mixing (about $8 \mathrm{~cm}$; Figure 1) corresponds to about 47 years at an accumulation rate of $0.17 \mathrm{~cm} / \mathrm{yr}$. The mixing blurs signals of discrete events, spreading evidence of the event into sediments deposited both before and after the event.

Two important tests exist from which to judge the accuracy of the radiocarbon ages. The first is the fact that the age of the sediment-water interface is zero at the time a core was taken (less than zero for radiocarbon ages, whose conventional zero point is $1950 \mathrm{AD})$. The shallowest ${ }^{14} \mathrm{C}$ ages clearly are not compatible with this constraint, nor with the presence of significant ${ }^{137} \mathrm{Cs}$ and excess ${ }^{210} \mathrm{~Pb}$ in the upper parts of cores within the lake. In addition, the ages from the $\mathrm{K} 1$ and $\mathrm{C} 7$ cores, taken at the same site at the same time, are such that a single correction, such as that appropriate for a constant reservoir effect, is not feasible (Figure 3).
Consequently, the radiocarbon ages in the uppermost parts of the cores were not used in constructing age models for each site.

The reason for the anomalous radiocarbon ages in the upper part of the cores is not entirely known. The simplest explanation is that they are the result of terrestrial organic carbon that has resided for some time on the landscape before being deposited in the lake. The magnitude of the effect is such that the upper few ages for cores $\mathrm{K} 1$ and $\mathrm{HB}$ project to an age at the sediment-water interface of about $700-800{ }^{14} \mathrm{C}$ years. As discussed below, radiocarbon ages lower in the cores show much less of an effect due to old carbon. The greater abundance of old carbon in the upper part of the section may be due to changes in the hydrology of the lake and its surrounding marshes, or in more recent times, to man-made drainage of the marshes, which would release old carbon stored there.

The other major test of the radiocarbon ages is provided by the occurrence of the Mazama tephra in cores $\mathrm{K} 1$ and $\mathrm{CM} 2$. This ash has been repeatedly dated in other settings (Bacon 1983; SarnaWojcicki et al. 1991; Hallet et al. 1997) and is now estimated to be 7550 cal yr BP. A precursor tephra, the Tsoyowata, occurs in core $\mathrm{K} 1$ and has been dated at 7870 cal yr BP (Sarna-Wojcicki et al. 1991). The radiocarbon age from immediately above the Mazama ash in core CM2 is indistinguishable from the age of the ash and is directly in line with ages higher and lower in the core. This TOC age at this site thus appears to be accurate. In contrast, five ages in and around the horizons that contain the Mazama and Tsoyowata tephras in core $\mathrm{K} 1$ appear to be about 400 years too old (Table 2, Figure 3).

This 400-year anomaly is somewhat less than that at the tops of cores $\mathrm{K} 1$ and $\mathrm{C} 7$, and is expectable in this shallow site off the mouth of the Williamson River. It is assumed to be the result of detrital input of carbon that is somewhat older than the sediments (and endogenic carbon) with which it was deposited. Core CM2 may have been less susceptible to the effects of old carbon at the time of the Mazama eruption, because it was located in a marshy area on the margin of the open lake, far from major river input, and thus less susceptible to the influx of detrital carbon. An age on a wood fragment just below the Mazama tephra $(750 \mathrm{~cm})$ in core $\mathrm{K} 1$ is even older than the 
TOC age, underlining the problem with dating detrital materials.

Despite the problems with radiocarbon ages in the upper part of the core, a clear biostratigraphic horizon appears just below the limit of ${ }^{210} \mathrm{~Pb}$-derived age information. The percentage of the diatom Aulacosiera ambigua increases dramatically in the upper parts of all cores examined. We interpret this as a synchronous event throughout the lake (Bradbury et al. 2004b - this issue). The increase occurs at a depth of $44 \mathrm{~cm}$ in core C7, which, at a sedimentation rate of $0.172 \mathrm{~cm} / \mathrm{yr}$, corresponds to an age of 256 years. We have assigned this age, rounded to 260 years, to the depth at which A. ambigua increases in the other cores (Table 4).

For our final age model for each core, we assumed that the sediment-water interface has an age of zero, and that the A. ambigua increase occurred at about 260 years. For cores K1 and C7, we used an average rate of sedimentation of $0.172 \mathrm{~cm} / \mathrm{yr}$ derived from the ${ }^{210} \mathrm{~Pb}$ data in the uppermost part of the cores. Based on the comparisons with the age of the Mazama tephra, we corrected all of the TOC radiocarbon ages in core $\mathrm{K} 1$ by -400 years (Table 2), to account for detrital carbon; the ages in CM2 were not corrected. For the age models, we did not use any radiocarbon ages in the upper part of the cores that were incompatible with these data (Table 2).

The remainder of the radiocarbon ages on TOC were used in the age models, at face value for cores $\mathrm{CM} 2$ and $\mathrm{HB}$, and with a correction of -400 years for K1. The Mazama and Tsoyowata tephras with their respective ages formed additional data points. In core $\mathrm{K} 1$, the line between the two lowest age control points was projected to the base of the core, yielding an age of $14700 \mathrm{cal} \mathrm{yr}$ BP. For core CM2, the age model was drawn through the remaining radiocarbon ages, and through the ages of the Trego Hot Springs and the Mt. St. Helens 'C' tephras. One of the radiocarbon ages, $26460 \mathrm{cal}$ yr BP, did not fit this trend, and was not used in the age model, as indicated in Table 2. Based on the slope of the age-depth relation in the lower part of $\mathrm{CM} 2$, the age of its base is estimated to be about 45200 cal yr BP.

In the final age models (Tables 4 and 5, Figure 3), radiocarbon ages less than $20265{ }^{14} \mathrm{C}$ yr BP were converted to calibrated ages using the CALIB
Table 4. Age model control points.

\begin{tabular}{|c|c|c|}
\hline $\begin{array}{l}\text { Corrected } \\
\text { depth }(\mathrm{cm})\end{array}$ & $\begin{array}{l}\text { Calibrated } \\
\text { age (kyr BP) }\end{array}$ & Explanation \\
\hline \multicolumn{3}{|l|}{ Core K1 } \\
\hline 0 & 0 & Surface \\
\hline 44 & 0.26 & A. ambigua correlation to $\mathrm{C} 7$ \\
\hline 181 & 1.55 & Radiocarbon estimate \\
\hline 234 & 2.09 & Radiocarbon estimate \\
\hline 342 & 3.35 & Radiocarbon estimate \\
\hline 555 & 5.53 & Radiocarbon estimate \\
\hline 659 & 7.39 & Radiocarbon estimate \\
\hline 704 & 7.55 & Mazama \\
\hline 711 & 7.87 & Tsoyowata \\
\hline 811 & 11.01 & Radiocarbon estimate \\
\hline 919 & 14.7 & Projected \\
\hline \multicolumn{3}{|l|}{ Core $\mathrm{C} 7$} \\
\hline 0 & 0 & Surface \\
\hline 26 & 0.15 & $\mathrm{~Pb}-210 \mathrm{SR}=0.172$ \\
\hline 44 & 0.26 & A. ambigua $; \mathrm{SR}=0.172$ \\
\hline \multicolumn{3}{|l|}{ Core CM2 } \\
\hline 0 & 0 & Surface \\
\hline 34 & 0.26 & A. ambigua correlation to $\mathrm{C} 7$ \\
\hline 50 & 2.79 & Radiocarbon estimate \\
\hline 110 & 3.88 & Radiocarbon estimate \\
\hline 172 & 4.93 & Radiocarbon estimate \\
\hline 202 & 6.22 & Radiocarbon estimate \\
\hline 248 & 6.54 & Radiocarbon estimate \\
\hline 300 & 7.43 & Radiocarbon estimate \\
\hline 323 & 7.58 & Radiocarbon estimate \\
\hline 328 & 7.55 & Mazama tephra \\
\hline 388 & 9.61 & Radiocarbon estimate \\
\hline 458 & 13.26 & Radiocarbon estimate \\
\hline 468 & 14.03 & Radiocarbon estimate \\
\hline 530 & 16.50 & Radiocarbon estimate \\
\hline 620 & 17.49 & Radiocarbon estimate \\
\hline 700 & 18.30 & Radiocarbon estimate \\
\hline 805 & 22.32 & Radiocarbon estimate \\
\hline 899 & 24.74 & Radiocarbon estimate \\
\hline 1000 & 33.70 & Radiocarbon estimate \\
\hline 1075 & 32.83 & Radiocarbon estimate \\
\hline 1236 & 42.59 & MSH 'C' tephra \\
\hline 1290 & 45.20 & Projected \\
\hline \multicolumn{3}{|l|}{ Core HB } \\
\hline 0 & 0 & Surface \\
\hline 16 & 0.26 & A. ambigua correlation to $\mathrm{C} 7$ \\
\hline 62 & 2.18 & Radiocarbon estimate \\
\hline 133 & 5.31 & Radiocarbon estimate \\
\hline 160 & 6.50 & Projected from 2 above \\
\hline
\end{tabular}

4.3 program (Stuiver et al. 1998). Ages greater than $20265{ }^{14} \mathrm{C}$ yr BP were converted to calibrated years using the relationship developed by Bard et al. (1998). The equation used is:

$$
\begin{aligned}
A= & -3.0126 \times 10^{-6} \times C^{2}+1.2896 \times C \\
& -1005
\end{aligned}
$$


Table 5. Age-depth function for core CM2.

\begin{tabular}{|c|c|c|c|}
\hline $\begin{array}{l}\text { Depth } \\
(\mathrm{cm})\end{array}$ & $\begin{array}{l}\text { Interpolated } \\
\text { age (cal yr BP) }\end{array}$ & $\begin{array}{l}\text { Depth } \\
(\mathrm{cm})\end{array}$ & $\begin{array}{l}\text { Interpolated } \\
\text { age (cal yr BP) }\end{array}$ \\
\hline 0 & 0 & 680 & 19.10 \\
\hline 34 & 0.26 & 700 & 19.64 \\
\hline 60 & 2.98 & 720 & 20.17 \\
\hline 80 & 3.39 & 740 & 20.70 \\
\hline 100 & 3.81 & 760 & 21.24 \\
\hline 120 & 4.23 & 780 & 21.77 \\
\hline 140 & 4.64 & 800 & 22.31 \\
\hline 160 & 5.06 & 820 & 22.80 \\
\hline 180 & 5.47 & 840 & 23.28 \\
\hline 200 & 5.89 & 860 & 23.76 \\
\hline 220 & 6.22 & 880 & 24.25 \\
\hline 240 & 6.54 & 900 & 24.73 \\
\hline 260 & 6.82 & 920 & 25.31 \\
\hline 280 & 7.07 & 940 & 25.88 \\
\hline 300 & 7.32 & 960 & 26.46 \\
\hline 320 & 7.61 & 980 & 27.04 \\
\hline 340 & 8.19 & 1000 & 27.61 \\
\hline 360 & 8.81 & 1020 & 29.33 \\
\hline 380 & 9.42 & 1040 & 31.05 \\
\hline 400 & 10.31 & 1060 & 32.77 \\
\hline 420 & 11.37 & 1080 & 34.33 \\
\hline 440 & 12.43 & 1100 & 35.39 \\
\hline 460 & 13.49 & 1120 & 36.45 \\
\hline 480 & 14.20 & 1140 & 37.51 \\
\hline 500 & 14.63 & 1160 & 38.56 \\
\hline 520 & 15.07 & 1180 & 39.62 \\
\hline 540 & 15.54 & 1200 & 40.68 \\
\hline 560 & 16.03 & 1220 & 41.74 \\
\hline 580 & 16.51 & 1240 & 42.78 \\
\hline 600 & 17.00 & 1260 & 43.75 \\
\hline 620 & 17.49 & 1280 & 44.72 \\
\hline 640 & 18.03 & 1290 & 45.20 \\
\hline 660 & 18.56 & & \\
\hline
\end{tabular}

where $A$ is calibrated age and $C$ is the age in radiocarbon years.

With the age-depth control points discussed above, several options exist for a final age model. The most straight-forward and objective option is to simply connect the individual control points with straight lines, so that ages between the control points can be calculated by linear interpolation. This method has the advantage of honoring all of the control points. Another option is to fit some sort of mathematical expression to the data. This method has the advantage of minimizing the effects of inaccuracies in individual data points.

Rosenbaum and Reynolds (2004 - this issue) calculated the relative proportions of biogenic silica, weathered lithic material, and fresh rock flour in the sediments from the CM2 core. These

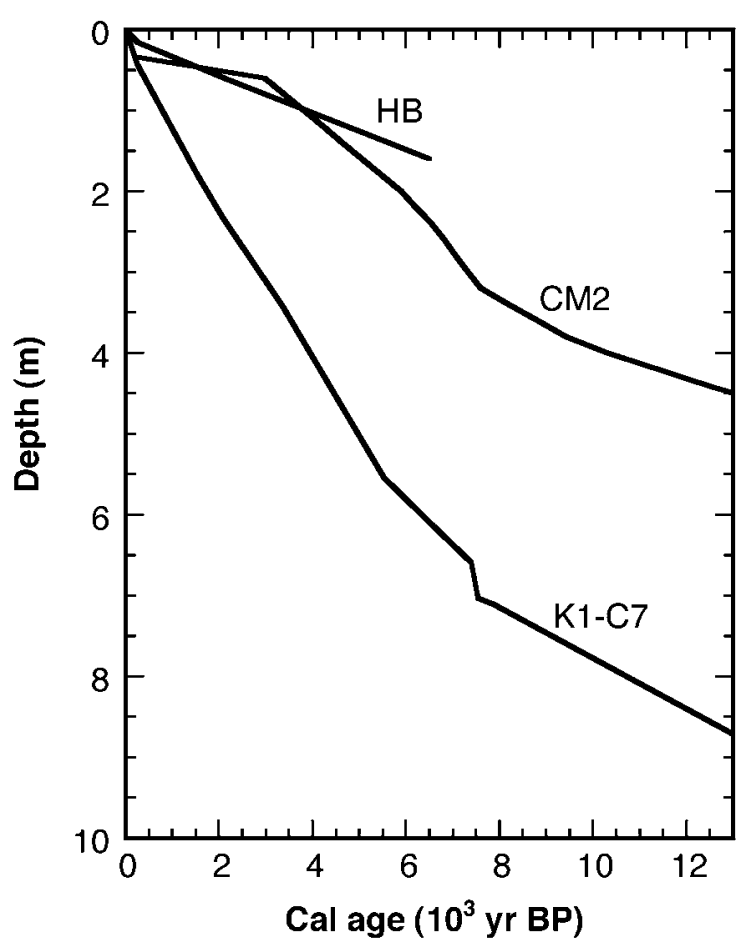

Figure 4. Comparison of age models for the last 13000 calibrated years for cores sites C7A-K1 and CM2-HB. Data from Table 4.

data, along with bulk densities, can be combined with age-depth relations to calculate the fluxes of various components of the sediments. The fluxes, in turn, are sensitive and powerful indicators of paleoenvironmental conditions. However, the flux calculations are very sensitive to the slope of the age-depth function and to any discontinuities in the relationship. For these reasons, Rosenbaum and Reynolds (2004 - this issue) used a smooth mathematical function relating age to cumulative mass of weathered material in the CM2 core (Figure 3B, 'flux model'). We used a local leastsquares fit method for core CM2, which comprises a series of line segments (Figure 3B, 'linear model'). This relation has been converted into age versus depth at 20-cm intervals (Table 5). The two fit methods are extremely close, well within the errors of the radiocarbon ages. For core K1, for which flux values are not available, we used the linear interpolation between the age control points (Table 4, Figure 3A).

The age-depth plots for the last 13000 years for cores $\mathrm{CM} 2$ and $\mathrm{K} 1$ are remarkably similar in shape 
(Figure 4), suggesting that sediment accumulation rates at the two sites responded to similar forcing, probably climate change. Overall, sediment accumulated at site $\mathrm{K} 1$, near the center of the basin, about two times faster than at site CM2, on the margin of the lake, about 0.10 versus $0.05 \mathrm{~cm} / \mathrm{yr}$. The data also indicate that accumulation rates were slower during the early to middle Holocene than during the late Holocene. This relationship is consistent with generally drier conditions in the early to middle Holocene in the Pacific Northwest (Whitlock and Bartlein 1997).

\section{Conclusions}

Determining the chronology of sediment deposition in Upper Klamath Lake, as in most lakes, is subject to a variety of difficulties. Each of the methods applied, in this case tephrochronology and ${ }^{14} \mathrm{C},{ }^{210} \mathrm{~Pb}$, and ${ }^{137} \mathrm{Cs}$ measurements, has its own difficulties and uncertainties. However, the combination of these methods can be used to infer a robust chronology for sedimentation in Upper Klamath Lake. Problems encountered with radioisotope methods include physical and biological mixing of surficial sediments and mobility of ${ }^{137} \mathrm{Cs}$. These problems limit the usefulness of the ${ }^{137} \mathrm{Cs}$ and ${ }^{210} \mathrm{~Pb}$ data, but ${ }^{210} \mathrm{~Pb}$ profiles provide reasonable average sediment accumulation rates for the last 100-150 years. Detrital organic carbon, older than the sediments in which it was deposited, appears to be the most serious problem in interpreting radiocarbon ages. The problem is especially serious near the tops of the cores, where the ages are somewhat erratic and are too old. This problem may have become more common in recent times as surrounding marshes were drained, releasing detrital materials that were otherwise trapped in the marshes. In addition, radiocarbon ages in cores from the center of the basin appear to be about 400 years too old, while those on the margin appear to be accurate, based on comparisons with tephra layers of known age.

The various chronological data can be combined into reasonable age models for each site. Sediments have accumulated at site $\mathrm{K} 1$, near the center of the basin, about two times faster than at site $\mathrm{CM} 2$, on the margin of the lake. The rates are about 0.10 and $0.05 \mathrm{~cm} / \mathrm{yr}$, respectively. The chronological data also indicate that accumulation rates were slower during the early to middle Holocene than during the late Holocene, consistent with increasing wetness in the late Holocene.

\section{Acknowledgements}

We thank David Adams for his initial leadership of the Klamath Lakes Drilling Project, and Jacob Kann for his help with our later operations on Upper Klamath Lake. Helpful reviews were provided by R.M. Forester, B. Haskell, and R.N. Oldale. This project was supported by the Global Change and Climate History (now Earth Surface Dynamics) Program of the US Geological Survey.

\section{References}

Appleby P.G. and Oldfield F. 1978. The calculation of ${ }^{210} \mathrm{~Pb}$ dates assuming a constant rate of supply of unsupported ${ }^{210} \mathrm{~Pb}$ to the sediment. Catena 5: 1-8.

Bacon C.R. 1983. Eruptive history of Mount Mazama and Crater Lake Caldera, Cascade Range, USA. J. Volcan. Geothermal Res. 18: 57-115.

Bard E., Arnold M., Hamelin B., Tisnerat-Laborde N. and Cabioch G. 1998. Radiocarbon calibration by means of mass sectrometric ${ }^{230} \mathrm{Th} /{ }^{234} \mathrm{U}$ and ${ }^{14} \mathrm{C}$ ages of corals: $\mathrm{An}$ updated database including samples from Barbados, Mururoa, and Tahiti. Radiocarbon 40: 1085-1092.

Bond C.E., Hazel C.R. and Vincent D. 1968. Relations of nuisance algae to fishes in Upper Klamath Lake. Terminal Report to FWPCA, Dept. of Fisheries and Wildlife, Oregon State University, $119 \mathrm{pp}$.

Bradbury J.P., Colman S.M. and Dean W.E. 2004a. Limnological and climatic environments at Upper Klamath Lake, Oregon during the past 45000 years. J. Paleolim. 31: 167-188 (this issue).

Bradbury J.P., Colman S.M. and Reynolds R.L. 2004b. The history of recent limnological changes and human impact on Upper Klamath Lake, Oregon. J. Paleolim. 31: 151-165 (this issue).

Brenner M., Peplow A.J. and Schelske C.L. 1994. Disequilibrium between ${ }^{226} \mathrm{Ra}$ and supported ${ }^{210} \mathrm{~Pb}$ in a sediment core from a shallow Florida lake. Limnol. Oceanogr. 39: 1222-1227.

Colman S.M., Bradbury J.P. and Rosenbaum J.G. 2004. Paleolimnology and paleoclimate studies in Upper Klamath Lake, Oregon. J. Paleolim. 31: 129-138 (this issue).

Eilers J.M., Kann J., Cornett J., Moser K., St. Armand A. and Gubala C.P. (in press). Recent Paleolimnology of Upper Klamath Lake, Oregon. Hydrobiologia.

Hallet D.J., Hills L.U. and Clague J.J. 1997. New accelerator mass spectrometer radiocarbon ages for the Mazama tephra layer from Kootenay National Park, British Columbia, Canada. Can. J. Earth Sci. 34: 1202-1209. 
Kann J. 1997. Ecology and water quality dynamics of a shallow hypereutrophic lake dominated by cyanobacteria (Aphanizomenon flos-aque). PhD dissertation, University of North Carolina, Chapel Hill, North Carolina, 110 pp.

Laenen A. and LeTourneau A.P. 1996. Upper Klamath Lake nutrient loading study - Estimate of wind-induced resuspension of bed sediment during periods of low lake elevation. US Geological Survey Open-File Report 95-414, 11 pp.

Martin E.A. and Rice C.A. $1981 .{ }^{210} \mathrm{~Pb}$ geochronology and trace metal concentrations of sediments from Upper Klamath Lake and Lake Euwana, Oregon. Northwest Sci. 55: $269-289$.

Oldfield F., Appleby P.G. and Lund J.W.G. 1984. Empirical testing of ${ }^{210} \mathrm{~Pb}$-dating models for lake sediments. In: Haworth E.Y. (ed.), Lake Sediments and Environmental History, Leicester University Press, Leicester, pp. 93-124.

Robbins J.A. 1978. Geochemical and geophysical applications of radioactive lead. In: Nriagu J.O. (ed.), Biogeochemistry of Lead in the Environment, Elsevier Scientific Publ., Amsterdam, pp. 285-293.

Robbins J.A. and Edgington D.N. 1975. Determination of recent sedimentation rates in Lake Michigan using $\mathrm{Pb}-210$ and Cs-137. Geochim. Cosmochim. Acta 39: 285-304.

Rosenbaum J.G. and Reynolds R.L. 2004. Record of Late Pleistocene glaciation and deglaciation in the southern Cascade Range: II. Flux of glacial flour in a sediment core from Upper Klamath Lake. J. Paleolim. 31: 235-252 (this issue).

Sanville W.D., Powers C.F. and Gahler A.R. 1974. Sediments and sediment-water nutrient interchange in Upper Klamath
Lake, Oregon. US Environmental Protection Agency Report EPA-660/3-74-015, 45 pp.

Sarna-Wojcicki A.M., Lajoie K.R., Meyer C.E., Adam D.P. and Reick H.J. 1991. Tephrochronologic correlation of upper Neogene sediments along the Pacific margin, conterminous United States. In: Morrison R.B. (ed.), Quaternary Non-Glacial Geology: Conterminous United States, Geological Society of America, Decade of North American Geology, vol. K-2, Boulder, Colorado, pp. $117-140$.

Schelske C.L., Brenner M., Peplow A. and Spencer C.N. 1994. Low-background gamma counting: applications for ${ }^{210} \mathrm{~Pb}$ dating of sediments. J. Paleolim. 10: 115-128.

Stuiver M. and Pollach H.A. 1977. Discussion - Reporting ${ }^{14} \mathrm{C}$ data. Radiocarbon 19: 355-363.

Stuiver M., Reimerand P.J. and Braziunas T.F. 1998. Highprecision radiocarbon age calibration for terrestrial and marine samples. Radiocarbon 40: 1127-1151.

Vogel J.S., Southon J.R., Nelson D.E., Brown T.A., Polach H.A. and Anderson H.H. 1984. Performance of catalytically condensed carbon for use in accelerator mass spectrometry. In: Wolfi W. (ed.), Proceedings of the 3rd International Symposium on Accelerator Mass Spectrometry, Nuclear Instruments and Methods in Physics Research B233, pp. 289-293.

Whitlock C. and Bartlein P.J. 1997. Vegetation and climate change in northwest America during the past $125 \mathrm{kyr}$. Nature 388: 57-61.

Wright H.E. 1967. A square-rod piston sampler for lake sediments. J. Sediment. Petrol. 37: 975-976. 